\title{
Likelihood Rating of Fraud Risk in Government Procurement
}

\author{
Mustofa Kamal' ${ }^{1}$, Andilo Tohom ${ }^{2}$ \\ BPKP Training Educaton Centre and Master's program at the Faculty of Law of Djuanda University Bogor, Indonesia ${ }^{1}$ \\ ${ }^{2}$ BPKP Training Educaton Centre and Doctoral Programme of Institut Pertanian Bogor, Indonesia ${ }^{2}$
}

\begin{abstract}
Indonesian government procurement regulations have undergone some changes towards improvements in procurement governance from 2003 to 2018 . However, the facts of 177 corruption cases in procurement [1] showed an increasing trend from 2004 to 2017. This study aimed to prove the likelihood level of risk of fraud government procurement and exemplify a list of government procurement fraud risk ratings. Qualitative research method is used with survey technique via google form to 52 respondents consisting of procurement group, auditor and procurement trainer or risk management trainer. Prospectively, respondents rated likelihood on 66 risk of procurement fraud. The findings of the research proposed that 66 score level of likelihood rating of 66 fraud risk in Government Procurement. The results showed that there are 5 risks have a "frequent" likelihood, there are 54 risks have "occasionally" likelihood, and 7 risks have "almost never" likehood. These results have implications for government agencies to develop proper response or management of procurement fraud risk in accordance with their likelihood. This study has limited research in the form of demographic data of survey respondents not disclosed.
\end{abstract}

Keywords: likelihood, procurement fraud risk, prospective

Article History. Received January, 2019. Revised March, 2019. Accepted June, 2019

Corresponding Author. Email. ${ }^{1}$ kamalopek.bpkp@gmail.com, ${ }^{2}$ andilo.tampubolon@gmail.com

How to cite article. Kamal, M., \& Tohom, A. (2019). Likelihood Rating of Fraud Risk in Government Procurement. The International Journal of Business Review (The Jobs Review), 2(1), 29-38. https://doi.org/https://doi.org/10.17509/tjr.v2i1.17903

\section{INTRODUCTION}

Procurement fraud is a second largest among 7 fraud case prosecuted by Indonesia's Corruption Eradication Commission (Komisi Pemberantasan Korupsi, abbreviated as KPK) from 2004 to 2017 (KPK, 2018). There are 171 Procurement fraud or 25\% of 688 fraud case in that period. It portrayed an increasing trend from number of procurement corruption are two event in 2004 to fifteen event in 2017.

The data reveal the fact that, to date, Procurement of Government Good, abbreviated as PBJP, actors have not been optimally managing the risk of PBJP fraud. Probably, they may not know or capable to manage or control the fraud risk in an accountable manner. On the other hand, there are mandatory from Government Regulation number 60 of 2008 about Government Internal Control System. There are, at a minimum, two obligations relating to the management and or control of risks, namely, risk assessment and control activities. There are also procurement contract control mandat from Presidential Regulation number 16 of 2018 about Procurement of Government Goods. The above conditions reflect a gap between reality within the mandatory expectation.

Some research object on likelihood fraud assessment using private organization. Jaffar et al (2011) proved that there is no personality factor that moderates the influence of the relationship between the ability of the external auditor to detect fraud and the likelihood of fraud. While Aghghaleh et al (2014) proves that the increase in sales and accounts receivable accounts positively associated with fraud likelihood. Meanwhile, Donelson et al (2017) 
proved the weakness of entity-level control has a high influence on the possibility of financial statements fraud incident.

This study will assess the likelihood of procurement fraud risk in the public sector. One way to identify risk is by prospective method (Nurhayati, 2010). So there are research question is; how to conduct prospective fraud risk assessment on government procurement? Therefore this study aims to give an example; list of the likelihood of government procurement fraud risk.

\section{Risk Management}

In general, risk can be defined as a situation faced by a person or organization where there is an adverse possibility or consequence of deviation from the outcome to be achieved (LKPP, 2016). The risk may also be an occurrence that may occur and if it occurs will have a negative impact on the achievement of the objectives of government agencies (Government Regulation number 60 of 2008). Therefore risk must be well managed.

Risk management is part of the organization's key business processes in both the private and public sectors worldwide (AS/NZS, 2004). Risk management is a coordinated effort of the organization to direct and control risk. Risk Management Process (figure 1); is the systematic implementation of management policies, management procedures and practices in the execution of tasks for communication and consultation, establishing the context, identifying, analyzing, evaluating, treating, monitoring and assessing risks (LKPP, 2016).

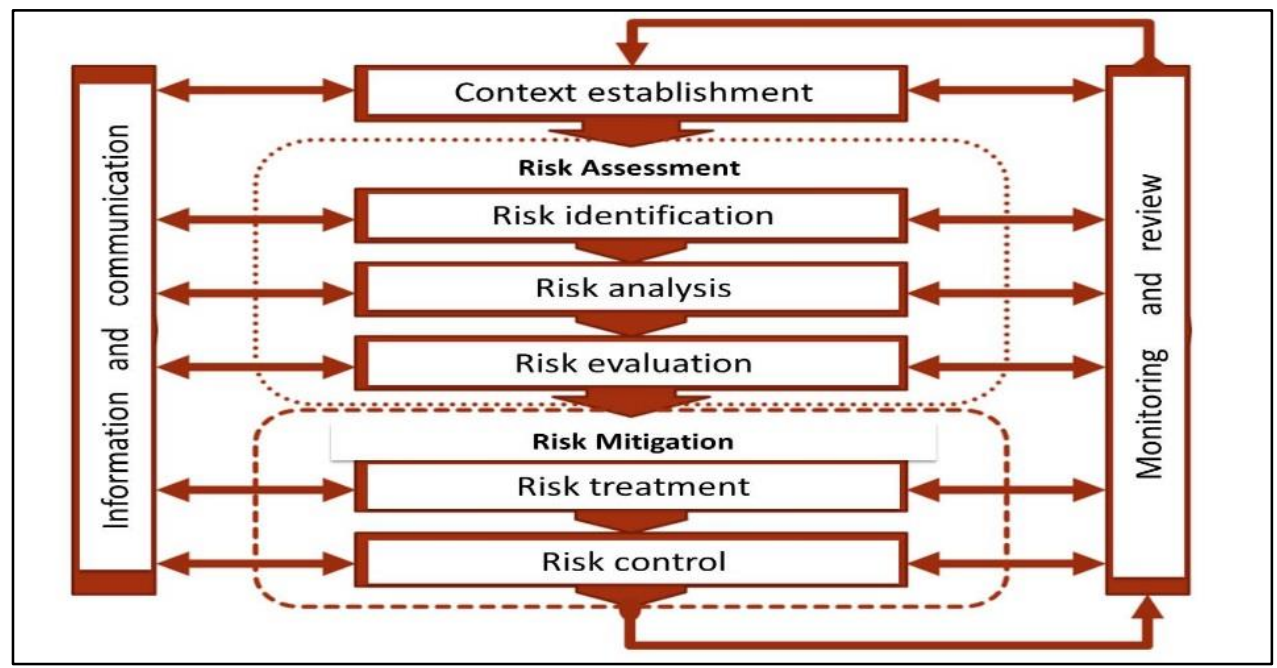

Figure 1. Risk Management Process

Source: LKPP, 2016

The context establishment process is the context in which the risk management process is applied. This includes organizational goals, strategies, scope, organizational activity parameters, or other areas where risk management is applied. The determination of the context is carried out by the organization's management to determine internal or external limits or parameters to be considered in risk management, determining the scope of work, and risk criteria for subsequent processes. The defined context must include all relevant internal and external parameters for the organization (Fachrudin and Erdhianty, 2015). The context of risk management in this research is an activity of Government Procurement. 
The organization shall establish the risk criteria to be used for the risk assessment stage, particularly to evaluate the hazard level of a risk. Risk criteria can be a reflection of organizational values, organizational goals, and impacts on the resources the organization has. Criteria to consider include: a) Impact criteria, ie what impacts should be used as criteria for assessments resulting from risks, such as financial impact, impact on health and life, legal impact, etc.; b) How to measure the possibility of likelihood '? Whether by using statistics (probability), the frequency of occurrence per unit time, or with expert judgment ?; and c) How to develop risk level criteria? At what risk rank does a risk require further treatment and which rank can we take for granted? This is necessary to prioritize risk handling (Fachrudin and Erdhianty, 2015).

An important part of risk management is the identification of risks. Risk identification methods can include qualitative and quantitative ranking activities, discussions at the leadership level, forecasts and strategic planning, as well as consideration of audit findings and evaluation of government internal control apparatus (Government Regulation number 60 of 2008). Organizations can also develop risk identification processes using a combination of internal surveys, interviews with various employees and the assistance of consultants (Nurharyanto, 2016). Organizations can also use two ways to identify risks by prospective and retrospective ways.

The prospective risk is the identification of risks that have not occurred yet but may occur sometime to come (Nurharyanto, 2010). This method requires imaginative thinking and proper experience (AS/NZS, 2004). The risk identification process can be compiled with the following scheme:

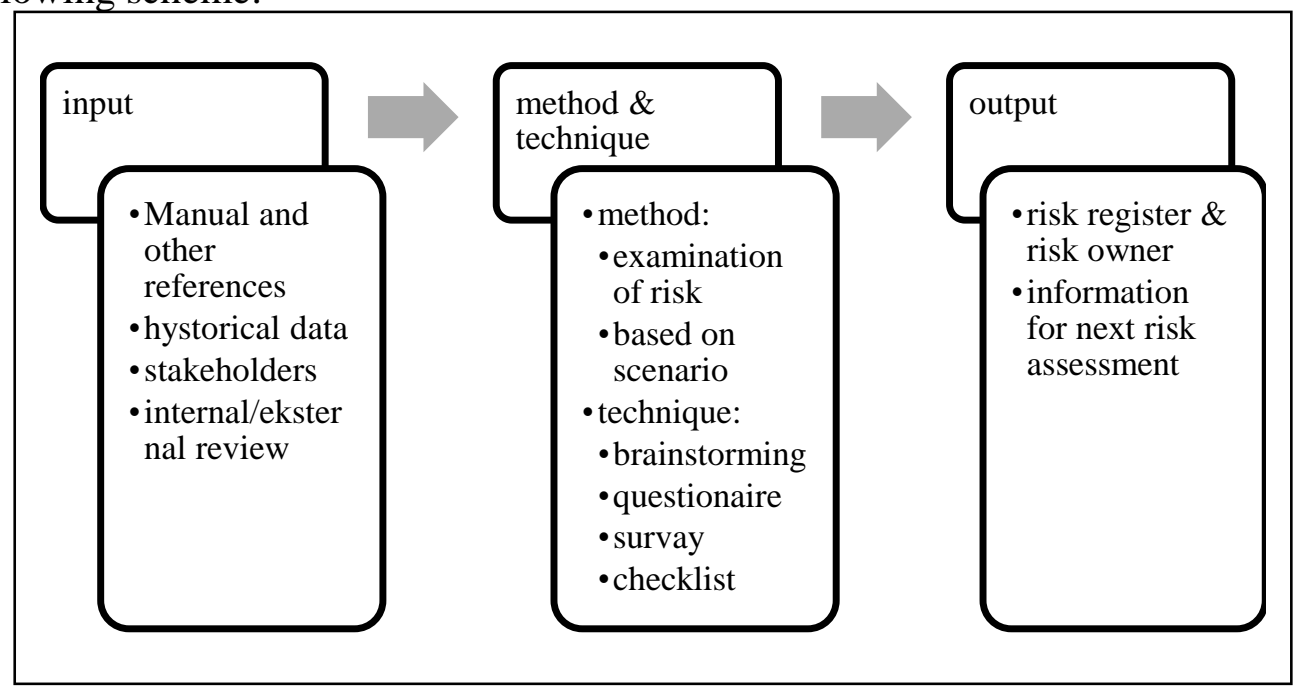

Figure 2. Risk Identification Process

Source: Nurharyanto dan Mirza, 2009, dan LKPP, 2016

Identified risks need to be analyzed to determine the level of incidence and its impact on achieving organizational goals. The possibility of fraud risk incidence can be measured using the likert scale. The immediate impact of risks is the delay in the target achievement of the activity, which is indicated by the increased cost or unfulfilled schedule of completion of an activity in a timely manner (Nurharyanto, 2016).

At the risk identification stage, in addition to identifying what the risks are, it should also be clearly identified who the risk owner is, who will be responsible for managing the remaining risk, or even the risks that require special handling. These risk owners determine how far the remaining risk is acceptable and determine whether additional risk treatment is required. The risk owner is also responsible for carrying out risk management and maintaining risk control and reporting information on risk (Fachrudin and Erdhianty, 2015). 
The risk analysis process begins by determining the level of likelihood and impact of identified risks. There are several ways of measuring the likelihood of risks. What method to be chosen depends on the availability of risk incident data. Where data is available, we can use probability method, ie a number between 0 and 1 . Number 0 indicates that the intended event is unlikely to occur. Conversely, the number 1 states that it must happen. However, to be able to determine what is the exact number of probabilities is not simple. This requires statistical process and mathematical model to know the distribution pattern. If there is no or very little data is available one may use the following ways: 1) Subjective Probability, ie the number of possibilities given by an expert in the relevant case and based on the various information and experience he/she has on the condition. The term "expert" here can also be the risk-owner himself. How to obtain it can be done through expert interview techniques and the results are often referred to as expert judgment; 2) Uniform distribution probability, which assumes all possibilities have equal opportunity to occur; or 3) Probability matrix is a table that provides a description of the possibility in the form of qualitative or quantitative, complete with the title (Fachrudin and Erdhianty, 2015).

\section{Fraud Risk}

The fraud risk is the degree of vulnerability faced by the organization/entity associated with the fulfillment of one of the elements in the fraud triangle, that is the motive/intent, opportunity, and rationalization of committing fraud, which if it becomes an incident would impact on the financial loss, performance and reputation of the organization/ either directly or indirectly (Nurharyanto, 2016).

Various studies related to the likelihood of fraud risk showed interesting results. The results of experimental studies conducted by Jaffar et al (2011) showed that there is no personality moderating factors influence the relationship between the external auditor's ability to detect fraud and likelihood of fraud. Research Aghghaleh et al (2014) by using a sample of some companies that never encountered fraud and corporate with fraud incident, proved that increase leverage and credit sales account has a positive effect with the likelihood of fraud. The size of the audit committee and the size of the board of directors decreases the fraudulent level of financial statements. Meanwhile, Donelson et al (2017) examined the relationship between internal control and the risk of financial reporting fraud by top managers. They believe in the theory that the weaknesses of internal control give managers greater opportunities to fraud, or give an indication of management characteristics that do not concern to the quality and integrity of reporting. Their research proves that the weakness of the entity's internal control (strategic level), not process level, has a higher impact on the risk of financial reporting fraud.

The emergence of fraud in Indonesia is largely due to the interference of administrative (bureaucratic) and political issues. Stages of fraud in the construction process can be found at the stage of project selection, feasibility studies, engineering design, procurement/procurement, contracts, supervision, construction and maintenance (Pandarangga et al 2013).

The risk of fraud needs to be managed and detected. The detection of fraud is influenced by the effectiveness of ongoing monitoring activity and whistleblowing, the effectiveness of fraud detection by internal and external auditors, the effectiveness of corruption cases investigation and prosecution by law enforcement officers, the effectiveness of corruption cases court, and effectiveness of corruptors sanctions (Kastowo, 2016). 


\section{METHOD}

This research used qualitative research method that is the type of research whose findings are not obtained through statistical procedures or other counts (Gunawan ,2015). The study use a prospective case study (figure 3) to find the tendency and trend drift of a case. Corrective action should not be done by researchers, but by others who are competent. Researchers only provide input from the research (Rahardjo, 2017).

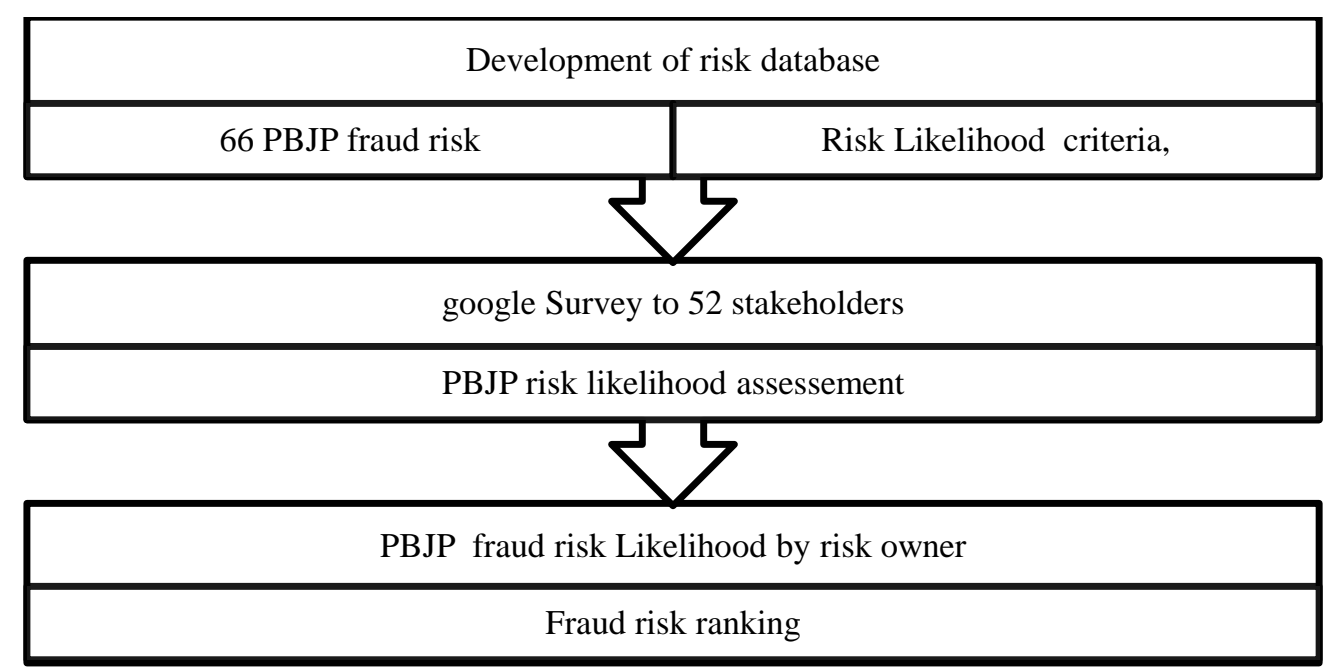

Figure 3. Research process of Prospective case study

Source: Rahardjo (2017), Nurharyanto dan mirza (2009), LKPP (2016), Fahrudin and Erdianthy (2015) dan AS/NZS 4360:2004

Development of risk database is conducted based on Alfian (2015) findings regarding risk in procurement. Based on his literature review and his experience as an auditor, he found 66 risks. These risks could happened in each of 15 stages of government procurement in Indonesia, from planning the procurement through delivery of the goods or services.

The purpose of this study which is to determine the likelihood level of the risks mentioned above, so it is necessary to measure the likelihood of PBJP risks. Since we have very little data available regarding PBJP fraud risk incident, we use the combination of following ways: 1) Subjective Probability, ie the number of possibilities given by an expert in the relevant case and based on the various information and experience he/she has on the condition. The term "expert" here can also be the risk-owner himself. In this research, we sent a questionnaire to 52 stakeholders consisting of PBJP actors, PBJP trainers, and internal government auditors through a survey via Google form) on Maret 2018; and 2) Probability matrix is a table that provides a description of the possibility in the form of qualitative or quantitative, complete with the title (Fachrudin and Erdhianty, 2015). Level of likelihood is assessed as follows; a value of 1 if almost never occurs, a value of 2 if occasionally, a value of 3 if it occurs frequently, a value of 4 if very frequent and a value of 5 if almost certainly occur. Last part of these research is risk owner identification of PBJP fraud risk, as a part of the risk register.

There are 52 respondent participated in the google survey from $13^{\text {rd }}-18^{\text {th }}$ of March, 2018 as shown in table 1.

Table 1. Respondent Characteristics

\begin{tabular}{ccc}
\hline Respondent Category & Position & Total \\
\hline PBJP & Budget User & 1
\end{tabular}

33 | The International Journal of Business Review (The Jobs Review) | Vol.2 | No.1 | 2019 
MUSTOFA KAMAL, ANDILO TOHOM/ Likelihood Rating of Fraud Risk in Government Procurement

\begin{tabular}{clc}
\hline \multirow{2}{*}{ Respondent Category } & \multicolumn{1}{c}{ Position } & Total \\
\hline \multirow{2}{*}{ Actors } & Proxy of Budget User & 1 \\
& Other Officer & 7 \\
& PBJP Functional Officer (Commitment-Making & 9 \\
& Officer, Procurement working group) & 18 \\
& Total PBJP actor & 8 \\
& First Auditor & 6 \\
& Junior Auditor & 4 \\
Auditor & Senior Auditor & 18 \\
\hline \multirow{2}{*}{ Trainer } & Total Auditor & 10 \\
& PBJP Trainer & 6 \\
& Risk Management Trainer & 16 \\
\hline & Total Trainer & $\mathbf{5 2}$ \\
\hline & Total Respondent &
\end{tabular}

\section{RESULTS AND DISCUSSION}

The fraud risk assessment can use the perceived management support and its effect on the organisation culture (Rubasundram, 2015). Meanwhile, there is also a significant interaction between brainstorming and auditors' expertise on the government auditors on fraud risk assessment (Daniel et al, 2016). Whereas Husaini and Bakar (2017) revealed that a proactive method for managing fraud risk is essential in minimizing exposure to fraudulent activities.

This study uses the perceptions of auditors, PBJP trainers, and PBJP actors. Perception data quality of 52 respondents tested its validity and reliability. The results of the validity test using the Pearson product moment indicate that all 66 risk statements are valid, correlation showed significant at 0,01 level (2-tailed). The reliability test results show alpha Cronbach score of 0.99 exceeding the 0.9 limit so that it can be concluded that all risk statements are perfectly reliable.

All of 52 respondents assessed the level of likelihood of 66 procurement fraud risks. The results show the assessment of the level of 66 fraud risk PBJP is divided into 3 categories of likelihood level. The results show that there are 5 risks have a "frequent" likelihood, there are 54 risks have "occasionally" likelihood, and 7 risks have "almost never" likehood. Tabel 2 exhibits the likelihood level according to its risk owner.

Table 2. Number and level of procurement fraud according to its risk owner

\begin{tabular}{lccc}
\hline \multirow{2}{*}{ Risk Owner } & \multicolumn{2}{c}{ Likelihood } & \multirow{2}{*}{ Number of risk } \\
\cline { 2 - 3 } & Level & Description & 3 \\
Budget User/Proxy of & 3 & Frequent & 6 \\
Budget User & 2 & Occasionally & 2 \\
Commitment-Making & 3 & Frequent & 10 \\
Officer & 2 & Occasionally & 38 \\
\hline procurement working & 2 & Occasionally & 7 \\
group & 1 & almost never & 66 \\
\multicolumn{2}{c}{ Number of procurement fraud risks } &
\end{tabular}


According to the respondents, there are 5 procurement fraud risks at highest likelihood. They assessed these risks at level 3 (frequent) as shown in table 3.

Table 3. Procurement fraud risk with the highest rank of likelihood

\begin{tabular}{|c|c|c|}
\hline Procurement fraud risks & Procurement stage & Risk Owner \\
\hline planning does not fit the real needs & Planning & Budget \\
\hline $\begin{array}{l}\text { planning tailored to the wishes of } \\
\text { certain parties }\end{array}$ & Planning & $\begin{array}{l}\text { User/Proxy } \\
\text { of Budget }\end{array}$ \\
\hline $\begin{array}{l}\text { goods / services leads to a particular } \\
\text { partner's ability }\end{array}$ & Planning & User \\
\hline $\begin{array}{l}\text { quality does not in accordance with } \\
\text { the contract }\end{array}$ & $\begin{array}{l}\text { Delivery of Goods / } \\
\text { Services and } \\
\text { Payment }\end{array}$ & $\begin{array}{l}\text { Commitment- } \\
\text { Making } \\
\text { Officer }\end{array}$ \\
\hline $\begin{array}{l}\text { Owner estimate not prepared based } \\
\text { on valid data }\end{array}$ & $\begin{array}{l}\text { Owner estimate } \\
\text { preparation }\end{array}$ & \\
\hline
\end{tabular}

Table 3 revealed that 3 fraud risks are the responsibility of Budget User/Proxy of Budget User, which is in the top management area. Then, if reviewed the description of the risk, it can be concluded that the three fraud risks are within the scope of internal control aspects of organizational planning. That is, there is a weakness of internal control at the top management level. This result is consistent with the research by Donelson et al (2017) which proved that the weakness of the entity's internal control (strategic level) has a higher impact on fraud risk.

To mitigate the above top management level risk, Government agencies need to develop a response or risk management of procurement fraud in accordance with the level of responsible management, especially at the top level management. It is consistent with what other scholar conclude by their research. Khorana et al (2015) study conclude that the need for a comprehensive approach to implementing an e-procurement framework that addresses insurance governance and assurance issues while ensuring transparency, accountability, competition and equity. Hoekman (2018) in his research suggest that policy should put emphasis on learning about good procurement practices, enhancing transparency and accountability, and promote a pro-competitive environment. Juwita and Ratna (2018) research regarding fraud risk in National Health Insurance (JKN) program conclude that without a strong, comprehensive and clear legal basis concerning the anti-fraud system, there will be risks of ambiguous tasks and duties of the authoritative organs and it will hamper the progress of protecting the JKN fund from fraudulent activities.

\section{CONCLUSION}

This study aims at giving an example of likelihood risk assessment of prospective government procurement fraud by 52 respondents. The study resulted 66 fraud risks. There are 5 risks with level "often occurring" likelihood, 54 risks at "occasionally" level, and 7 risks at "almost never" likelihood. Based on the list of risk ratings of government procurement fraud, it can be concluded that the three fraud risks are within the scope of internal control aspects of organizational planning. That is, there is a weakness of internal control at the top management level.

The results of this study have implications for government agencies to design an accountable risk assessment strategy. Government agencies need to develop a response or risk management of procurement fraud in accordance with the level of responsible 
management, especially at the top level management. This study has limited research in the form of demographic data of survey respondents not disclosed.

\section{REFERENCES}

Aghghaleh F.S., Mohd. I. T., Muhammaddun. M. Z. (2014). Fraud Risk Factors of Fraud Triangle and the Likelihood of Fraud Occurrence: Evidence from Malaysia, Information Management and Business Review 6, 1, 1-7.

Alfian. (2015). Pemetaan Jenis dan Risiko Kecurangan dalam Audit Pengadaan Barang dan Jasa, Jurnal Pengadaan 4, 1, LKPP, Jakarta

AS/NZS. (2004). Handbook Risk Management Guidelines Companion to AS/NZA 4360:2004, accesed at https://www.inxsoftware.com/media/transfer/doc/hb_436_2004_guidelines_ to_as_nzs_4360_2004_risk_management_guidelines_companion_to_as_nzs_4360_2 004.pdf, tanggal 12 Februari 2018

Danelson C, Matthew S, John M. (2017). Internal Control Weaknesses and Financial Reporting Fraud, Auditing: A Journal of Practice \& Theory, 36, 3, 2017 Pp. 45-69, DOI: 10.2308/ajpt-51608.

Daniel M., Nassir M., Sanusi Z. M., Ghani E.K. (2016). Effect of Brainstorming and Expertise on Fraud Risk Assessment. International Journal of Economics and Financial Issues, 2016, 6(S4) 62-67, Institute for Strategic and Sustainable Accounting Development (ISSAD), Tunku Puteri Intan Safinaz School of Accountancy, College of Business, Universiti Utara Malaysia, Malaysia

Fachrudin. M. \& Erdhianty. D. (2015). Manajemen Risiko Organisasi Sektor Publik, Modul Diklat Teknis Substansi, Pusdiklatwas BPKP, Bogor

Gunawan I. (2015). Metode Penelitian Kualitatif, Accessed At : http://fip.um.ac.id/wpcontent/uploads/2015/12/3_Metpen-Kualitatif.pdf

Hoekman, B. (2018). Reducing Home Bias in Public Procurement: Trade Agreements and Good Governance. Global Governance 24 (2018), 249-265

Husaini U. and Bakar A.A. (2017). Fraud Risk Management, Feature article, MARIM Risknews, Issue 1, 2017, https://www.researcgate.net/publication/331087397

Jaffar N, Hasnah.H, Mohd. I. T., Arfah. S. (2011). Fraud Risk Assessment and Detection of Fraud: The Moderating Effect of Personality, International Journal of Bussiness and Management 6, 7.

Juwita \& Ratna. (2018). Good Governance and Anti-Corruption: Responsibility to Protect Universal Health Care in Indonesia. Journal of Hasanuddin Law Review. 2018;4(2):162-180 DOI 10.20956/halrev.v4i2.1424 
Kastowo. M. (2016). Pemodelan Tindakan Koruptif: Analisis dengan Pendekatan Teori Pilihan Rasional dan Dilema Keagenan, Karya Tulis Ilmiah di Majalah Kampus Pengawasan, No.ISSN: 2442-8205, Januari 2016.

Khorana S. Ferguson .B.K., Kerr, William. (2015). Governance Issues in EU's eProcurement Framework : Journal of Common Market Studies, Volume 53. Number 2. pp. 292-310. DOI: $10.1111 / \mathrm{jcms} .12179$

KPK. (2018). TPK Berdasarkan Jenis Perkara, Accessed At: https://acch.kpk.go.id/id/statistik/tindak-pidana-korupsi/tpk-berdasarkan-jenisperkara.

LKPP. (2016). Mengelola Risiko, Buku Informasi UK 29 Pelatihan Fungsional PBJP, Tim Penyusun Materi Pelatihan Pengadaan Barang/Jasa LKPP, Direktorat Pelatihan Kompetensi Deputi Bidang Pengembangan Pembinaan Sumber Daya Manusia LKPP, Jakarta

Nurharyanto. (2010). Konsep dan Implementasi Risk Assessment, Modul Diklat Sistem Pengendalian Intern Pemerintah (SPIP) Dasar, Pusdiklatwas BPKP, Bogor

Nurharyanto. (2016). Pendekatan Teori Permainan dan Konsep Asesmen Risiko Fraud Untuk Melakukan Pencegahan dan Pendeteksian Fraud Pada Sektor Publik, Karya Tulis Ilmiah di Majalah Kampus Pengawasan, No.ISSN: 2442 - 8205, Januari 2016

Nurhayati.S. (2010). Identifikasi Risiko, Modul Diklat Manajemen Risiko, Pusdiklatwas BPKP, Bogor.

Pandarangga. A., Dwihatmoko, Utomo. J., dan Wibowo M. A. (2013). Studi Pemetaan Potensi dan Antisipasi Tindak Fraud Dalam Proyek Konstruksi, UNDIP, Semarang. Accessed At: https://adipandarangga.wordpress.com/2013/04/13/studi-pemetaanpotensi-dan-antisipasi-tindak-fraud-dalam-proyek-kostruksi/

Rahardjo M.H. (2017). Studi Kasus dalam Penelitian Kualitatif: Konsep dan Prosedurnya, Program Pascasarjana Universitas Islam Negeri Maulana Malik Ibrahim Malang, Accesed At: http://repository.uin-malang.ac.id/1104/1/Studi-kasus-dalam-penelitiankualitatif.pdf

Rubasundram G. A. (2015), Perceived "Tone From The Top" During A Fraud Risk Assessment, Procedia Economics and Finance 28 ( 2015 ) 102 - 106, 7th International Conference on Financial Criminology 2015 13-14 April 2015,Wadham College, Oxford, United Kingdom 